\title{
Die taak van akademiese geletterdheid/hede binne die konteks van 'n markgedrewe universiteit
}

\author{
Elsa Meihuizen \\ Sentrum vir Akademiese en Professionele Taalpraktyk, Noordwes-Universiteit, Potchefstroomkampus, Suid-Afrika \\ E-pos: Elsa.Meihuizen@nwu.ac.za
}

\section{Opsomming}

Die vestiging van Akademiese Geletterdheid by tersiêre instansies in Suid-Afrika het gegroei uit die besef dat 'n goedontwikkelde akademiese taalvermoë essensieel is vir akademiese prestasie. Gepubliseerde literatuur getuig van die belangrike verskuiwings wat oor die afgelope aantal dekades plaasgevind het in sowel die konsepsie as praktiese toepassing van intervensies vir die vestiging en/of ontwikkeling van hierdie essensiële vermoëns by ons studente. Hierdie tipe verskuiwings getuig van 'n gesonde dinamiek en is noodsaaklike groeipyne by 'n ontluikende akademiese dissipline. Hierdie referaat handel oor een van die veranderlikes wat verreken moet word in die vraag na die taak van Akademiese Geletterdheid, naamlik dié van kontemporêre verskuiwings in die aard van die universiteit as instansie. Daar word aangevoer dat die mees grondliggende van hierdie verskuiwings saamhang met 'n globale tendens wat neerkom op die algemene uitbreiding van 'n besigheids- of markgerigtheid as vertrekpunt en maatstaf vir alle areas van die sosiale lewe, insluitende openbare instansies soos universiteite. So 'n markgerigtheid gaan in die hedendaagse korporatiewe universiteit ook hand aan hand met toenemende burokratisering met 'n aandrang op die monitering, optekening, evaluering en verrekening van akademiese aktiwiteite as "uitsette". Ten einde ons eie ervaring van die institusionele karakter van die hedendaagse universiteit in perspektief te stel, word daar gekyk na aspekte van die geskiedkundige ontwikkeling van die universiteit as instansie en na ouer sowel as meer onlangse sienings van kritici in die breër internasionale arena. Die ontwikkeling van 'n kritiese bewussyn van hierdie tipe verskuiwings en die sosiale kragte wat dit onderlê en van die vermoë om 'n eie standpunt hieroor te verwoord word gesien as deel van die taak van Akademiese Geletterdheid, of eerder "Akademiese Geletterdhede" soos gekonsipieer in die werk van teoretici soos Brian Street en die New London Group. Ek wil 'n saak daarvoor uitmaak dat hierdie vakgebied die potensiaal én verantwoordelikheid het om 'n sentrale rol te speel binne die "nuwe" universiteit om ons studente voor te berei vir die "nuwe" wêreld waarheen ons hulle op weg moet help.

Sleutelwoorde: Akademiese Geletterdheid, universiteit, markgerigtheid, sosiale diskoers 


\section{The task of Academic Literacy/ies within the context of a market oriented university}

The establishment of Academic Literacy at tertiary institutions in South Africa is rooted in the realisation that a properly developed competency in academic language is a prerequisite for academic achievement. Published literature of the last few decades bears witness to the important shifts in the nature of interventions aimed at equipping our students with these essential competencies. Shifts like these mark a healthy, dynamic process of development in what can still be considered as an emerging academic discipline. In this paper I focus on one of the variables which should be taken into account in formulating the task of Academic Literacy, namely contemporary changes in the nature of the university as an institution. It is argued that the most fundamental of these changes concerns the global trend of marketisation of all areas of social life, including public institutions such as universities. Characteristic of the corporate university is an insistence on bureaucratic processes for documenting, monitoring, evaluating and measuring academic activities and "outputs". In order to provide a proper perspective on our own experience of the contemporary university, I consider aspects of the historical development of the university as an institution as well as views of international critics. The development of a critical consciousness of social changes and the forces underlying them, as well as the ability to formulate personal views in this regard, are seen as integral to the task of Academic literacy, or rather "Academic Literacies", by critics such as Brian Street and the New London Group. I would like to argue that this discipline has the potential and, indeed, the responsibility to play a central role within the "new" university in preparing our students for entering into a "new" world.

Key words: Academic literacy, university, marketisation, social discourse

\section{Inleiding}

Positief gestel, sou daar aangevoer kon word dat die vestiging van kursusse in Akademiese Geletterdheid by Suid-Afrikaanse universiteite gedurende die afgelope dekade of wat gegroei het uit ' $n$ waardering vir die feit dat studente bystand nodig het in die ontwikkeling van vermoëns wat essensieel is vir akademiese prestasie. 'n Alternatiewe, meer siniese, maar miskien ook meer feitelik korrekte interpretasie van hierdie ontwikkeling is egter ook moontlik, naamlik dat vir diegene met die besluitreg oor hierdie tipe aangeleenthede by universiteite dit nie sodanig gaan oor akademiese oorwegings nie, maar eerder oor rand-en-sent-kwessies soos deurvloeikoerse, subsidies, die prestige van die instansie, balansstate in jaarverslae, sakeplanne, ensovoort. Die sinisme wat die tweede interpretasie onderlê, is vandag redelik algemeen by sowel die publiek as akademici en dit is inderdaad ook verstaanbaar, gegewe die mate waartoe universiteite vandag as besighede bedryf word.

Hierdie artikel handel oor die aard van die universiteit as instansie, oor prosesse van kommersialisering en burokratisering waaraan die hedendaagse universiteit onderwerp is, en teen hierdie agtergrond oor die taak van Akademiese Geletterdheid. Hierdie taak word geplaas binne die raamwerk van 'n bepaalde definisie van "geletterdheid" wat fokus op die ontwikkeling van 'n kritiese bewussyn van die sosiale kragte werksaam in die gemeenskap wat verantwoordelik is vir verskuiwings in die aard van openbare instansies soos die universiteit. 


\section{Die universiteit as instansie}

\subsection{Dualiteit}

Kritici wat hulle uitspreek oor die aard en taak van die universiteit omskryf dit dikwels as tweevoudig: aan die een kant 'n praktiese bydrae tot die behoeftes van die gemeenskap, maar aan die ander kant ook iets méér. ${ }^{1}$ Die klassieke voorbeeld hiervan is te vinde in John Henry Newman se The idea of a university wat dateer uit 1873. Hy omskryf die taak van die universiteit as 'n "liberale opvoeding" ("liberal education") en voer aan dat die waarde van hierdie tipe opvoeding dikwels bevraagteken word deur diegene wat daarop aandring dat opvoeding prakties bruikbaar ("useful") moet wees, gerig op spesifieke uitkomste en vaardighede. Van mense met hierdie uitgangspunt sê Newman: "... they go on to ask what there is to show for the expense of a University; what is the real worth in the market of the article called "a Liberal Education" on the supposition that it does not teach us definitely how to advance our manufactures, or to improve our lands, or to better our civil economy; or again, if it does not at once make this man a lawyer, that an engineer, and that a surgeon; or at least if it does not lead to discoveries in chemistry, astronomy, geology, magnetism, and science of every kind" (Newman 1964(1873):116). In sy eie definisie van die taak van die universiteit sluit Newman nie die prakties bruikbare uit nie, maar wys daarop dat dit onafskeidbaar is van 'n bydrae tot die ontwikkeling van die breër intellektuele en spirituele lewe van die gemeenskap:

If then a practical end must be assigned to the University course, I say it is that of training good members of society. Its art is the art of social life, and its end is fitness for the world. It neither confines its views to particular professions on the one hand, nor creates heroes or inspires genius on the other./... It does not promise a generation of Aristoteles or Newtons, of Napoleons or Washingtons, of Raphaels or Shakespeares, though such miracles of nature it has before now contained within its precincts. Nor is it content on the other hand with forming the critic or the experimentalist, the economist or the engineer, though such too it includes within its scope. But a University training is the great ordinary means to a great but ordinary end: it aims at raising the intellectual tone of society, at cultivating the public mind, at purifying the national taste, at supplying true principles to popular enthusiasm and fixed aims to popular aspirations, at giving enlargement and sobriety to the ideas of the age, at facilitating the exercise of political power, and refining the intercourse of private life.

(Newman 1964(1873):134)

Hierdie dualiteit in die opvoedingstaak gaan saam met 'n ander tiperende dubbelslagtigheid by die universiteit as instansie, naamlik 'n spanning tussen selfberegtiging teenoor beheer van buite. Stefan Collini, die Cambridge-akademikus wat oor die afgelope aantal jare aansienlike prominensie verwerf het vir sy idees oor die aard en wese van die universiteit, sien hierdie spanning as reeds aanwesig in die prototipe vir die moderne universiteit, naamlik die Universiteit van Berlyn wat in 1810 deur die bemiddeling van Wilhelm von Humboldt, die destydse Pruisiese minister van opvoeding, tot stand gekom het:

\footnotetext{
${ }^{1}$ Vir voorbeelde van studies oor die aard van die universiteit waaruit hierdie seining blyk, kyk: Newman (1964(1873), Veblen (1918), Durrant (1959), Robertson (1999), Gray (1999a), Christensen en Eyring (2011), Bok (2003), Summerville (2006), Falkner (2011), Taylor (2011), Walton (2011), Collini (2012).
} 
From the outset, the German ideal embodied tensions which have, in one form or another, continued to mark universities to this day. Humboldt's university itself was a curious mixture of Lehrfreiheit and state control, a cross between a self-governing community of scholars and a collection of civil servants. In addition, there was the longstanding tension between serving a variety of social needs and being in some way withdrawn from society, even offering a form of resistance to the dominant values and practices of that society.

(Collini 2012:25)

Die Amerikaanse filosoof en teoloog, Mark Taylor, wys in sy werk Crisis on campus: a bold plan for reforming our colleges and universities (2010) daarop dat die rede vir hierdie spanning gevind kan word in die sosiale omstandighede waarin die moderne universiteit gekonsipieer is. Die bloudruk vir Von Humboldt se universiteit is naamlik vervat is in 'n geskrif getiteld Der Streit der Fakultäten ${ }^{2}$ wat in 1798 deur Immanuel Kant gepubliseer is. Kant se teks dateer uit 'n tydperk van groot sosiale verandering gedurende die vroeë fases van die industriële revolusie toe die onderwysstelsel van die Middeleeue uitgedien geraak het en vernuwing nodig was. Een van die belangrikste veranderings was dat die staat die kerk verplaas het as beskermheer en befondser van hoër onderwys. In hierdie nuwe omstandighede het universiteite 'n ooreenkoms met die staat aangegaan waarin hulle onderneem het om, in ruil vir gewaarborgde befondsing, opgevoede werkers te verskaf om posisies te vul in die staat se vinnig groeiende administratiewe burokrasie. Die universiteit sou dan die reg hê om sekere funksies te vervul deur sy fakulteite. Dit is in Kant se omskrywing van die fakulteite waarin die universiteit verdeel sou word dat die teenstrydige aard van die universiteit gewortel is. Die universiteit sou verdeel word in "hoër" en "laer" fakulteite met eersgenoemde bestaande uit teologie, regte en medisyne en laasgenoemde uit die "filosofiese fakulteite" wat alles insluit wat ons vandag ken as die geestesen natuurwetenskappe. Ten spyte van die benaming wat'n mens anders sou laat vermoed, sien Kant die lede van die laer fakulteite as outonoom in dié sin dat hulle hulle eie beginsels en funksies kan bepaal, terwyl die hoër fakulteite in hulle hoedanigheid as opleidingsforums vir die professies gesien word as instrumente van die regering met beperkte vryheid in die aanwending van hulle kennis. Die "konflik" wat Kant sien tussen die fakulteite is dan geleë in hierdie ongelykheid in outonomiteit. Taylor reken dat dit 'n berekende strategie was waarop Kant die staat tevrede kon hou en terselfdertyd die vryheid en onafhanklikheid van die intellek kon waarborg:

In contrast to the practical orientation of the higher faculties, the lower faculty extends the tradition of otherworldliness characteristic of medieval monasteries and universities to modern educational institutions. The arts and sciences in the philosophical faculty are not bound by utilitarian principles, but are designed to be "autonomous". Never yielding to personal, religious, political or economic interests, members of the philosophical faculty are supposed to be guided solely by the principles of pure universal reason, which is purportedly untainted by practical concerns./... the raison d'être of the arts and sciences is criticism. For critics devoted to purportedly disinterested inquiry, nothing compromises the purity of the faculty more quickly than government interference and the crass calculations of "businessmen and technicians of learning".

(Taylor 2010:54-55)

\footnotetext{
${ }^{2}$ In Engels vertaal deur Mary J. Gregor as The conflict of the faculties (1979).
} 
Plaaslik sowel as in breër internasionale verband bestaan daar vandag kommer oor die rigting waarin die institusionele karakter van die universiteit besig is om te ontwikkel. Hierdie ontwikkeling kom daarop neer dat die intellektuele en spirituele oorskadu word deur die prakties diensbare, en dat die mate van outonomiteit waarop die universiteit tradisioneel kon aanspraak maak, ook hierdeur geraak word. Die aanspreeklikheid vir hierdie toedrag van sake word hoofsaaklik gelê voor die deur van regerings wat in toenemende mate finansiële steun aan universiteite onttrek en van hierdie instansies verwag om soos besighede te funksioneer. Die volgende kommentaar van Couldry (2011:39) op die huidige Britse regering se hervormingplanne vir hoër onderwys en van die Browne-verslag ${ }^{3}$ waarop dit grootliks gegrond is, is tekenend hiervan:

What are we to make of a reform that apparently will lead to better and fairer funding of the English university system but in fact institutes a pure market mechanism that will completely transform the principles on which the English higher education system is built? The Browne report - commissioned by the New Labour government - moves decisively away from the principle that governments should support universities to provide access at the highest level to the full range of human knowledge, understanding and creativity and to ensure that young people have the opportunity to develop their full intellectual and creative potential, regardless of family wealth. In its place comes a much cruder principle that the only university functions government supports are those that meet the immediate needs of the economy ...

Lange (2012) se oorsig van die hervormingsinisiatiewe in hoër onderwys ná 1994 is besonder insiggewend vir die Suid-Afrikaanse konteks. Sy sonder vier hoofprioriteite van hierdie proses uit, en drie hiervan, naamlik "doeltreffendheid en effektiwiteit", "kwaliteitsbeheer" en "ontwikkeling", hou verband met groter aandrang van die regering op ekonomiese bydraes deur universiteite, hoewel, soos Lange aandui, dit nie altyd onmiddellik duidelik is uit die benoemings van die hervormingsprioriteite as sodanig nie. In verband met die prioriteit van "ontwikkeling" sê sy byvoorbeeld: "The fourth level of reform - development - was introduced in the policy under the rubric of responsiveness and development. Responsiveness was defined as the ability of higher education to meet the needs of an increasingly technologically oriented economy, to deliver research, highly trained people and the knowledge to address national needs and to participate in the global economy" (Lange 2012:51). Die tipiese besorgdheid oor die impak van hierdie tipe markgerigte regeringsbeleid op die institusionele karakter van die universiteit word as volg verwoord deur Singh (2012:2-3):

Fiscal discipline, efficiency and cost-benefit optimisation principles from the world of business are seen as the key to the transformation of higher education in the direction of greater responsiveness to society. Within a paradigm that invokes the 'market', the notion of responsiveness is becoming emptied of most of its content, except for that which advances individual, organisational or national economic competitiveness. The concept of an autonomous intellectual or socially emancipatory role for higher education, where it features, remains largely at the level of policy rhetoric, with little funding or other policy enabling factors in place to give substance to them. The consequences of such a one-sided approach to higher education responsiveness are severely impoverishing for the broader social role of higher education.

\footnotetext{
${ }^{3}$ Kyk: Browne (2010).
} 


\subsection{Die markgedrewe universiteit}

Besigheidspraktyke is natuurlik nie nuut binne die universiteitsopset nie. Universiteite moes byvoorbeeld nog altyd staatsubsidies aanvul deur verhaling van studentegeld, behoorlike finansiële bestuursmaatreëls was nog altyd 'n onontbeerlike onderdeel van die breër spektrum van administrasieprosedures, werwing van studente is 'n goedgevestigde praktyk en daar bestaan 'n lang tradisie van winsgewende samewerking met besighede op navorsingsgebired. Waar hierdie tipe aktiwiteite tradisioneel op die periferie aanwesig was, word dit egter nou op die voorgrond geplaas. ${ }^{4}$ Daar word byvoorbeeld op universiteite se webwerwe prominensie gegee aan kwessies soos "korporatiewe karakter" en "korporatiewe beheer". Op die webwerf van my eie universiteit word 'n beskrywing gegee van die organisasie-eenheid getiteld Korporatiewe Sake en Verhoudinge en die eerste twee punte van die missiestelling van hierdie eenheid is om die instansie "in die gedagtes van interne en eksterne belanghebbers te posisioneer as 'n gevestigde, lewendige, hoëkwaliteit- en entrepreneursuniversiteit" en "om 'n handelsmerkidentiteit en handelsmerkposisionering te skep" (NWU s.a.). 'n Afsonderlike afdeling onder die opskrif "Die beste in korporatiewe beheer" word gewy aan die prestasie van dié universiteit sedert 2007 in die jaarlikse PriceWaterhouseCoopers-toekenning vir Uitnemendheid in Hoër Onderwys (Korporatiewe Beheer) wat dit ten doel het om hoëronderwysinstellings aan te moedig om die hoogste standaarde in korporatiewe beheer te handhaaf. Hierdie tipe kompetisie word gefasiliteer deur die regering, en die handhawing van hierdie tipe uitnemendheid word deur die staat verwag ten spyte van die onttrekking of vermindering van finansiële ondersteuning, gewoonlik gemotiveer met verwysing na heersende ekonomiese omstandighede. Uiteindelik, en dit word deesdae algemeen deur vise-kanseliers, rektore en ander "bestuurders" as 'n ononderhandelbare voorwaarde gestel, is dit vir die universiteit 'n kwessie van oorlewing om aan te dring op praktyke wat ekonomies voordelig is. Hierdie praktyke sluit in:

- die handhawing van 'n kompeterende, aktiewe beleid van "groei", in die najaag van groter studentegetalle, meer navorsingsuitsette en surplusse op begrotings;

- aggressiewe bemarkingsveldtogte;

- "kwaliteitsbestuur" wat neerkom op die afdwing van reduksionêre standaardisering en optekening van akademiese aktiwiteite deur onpersoonlike moniteringstelsels soos gedikteer deur die Uitkomsgebaseerde Onderwysstelsel;

- 'n verhoogde aandrang daarop dat akademici op 'n volgehoue manier 'n altydtoenemende aantal "navorsinguitsette" produseer wat verreken word in SAPSE-eenhede met 'n gewaarborgde monetêre waarde;

- aansluitend hierby ' $n$ algemeengeldende sentiment dat dit wat nie in finansiële terme gemeet kan word nie, nie waardevol is nie, en mee weggedoen kan word (dit raak veral die Geesteswetenskappe wat dikwels gesien word as 'n luukse, as onbemarkbaar, en daarom sonder werklike waarde);

- die afskaling en uitfasering van poste en 'n toenemende gebruik van personeel in kontrakposte;

- verskerpte inisiatiewe vir finansiering van leerstoele, fasiliteite en navorsingsprojekte deur besighede;

${ }^{4}$ Bok (2003) fokus op hierdie tendens in Amerikaanse universiteite oor die afgelope 25 jaar. Ander voorbeelde van relevante bronne is: Binks (1999), Gray (1999a), Robertson (1999), Mazzarol en Soutar (2001), Collini (2010), Collini (2011), Christensen en Eyring (2011). 
- studente wat as kliënte gesien word en as sodanig tevrede gehou moet word om konstante verhogings in klasgeld te regverdig;

- 'n verhoogde premie op beroepsgerigte kursusse, wat ook na studente deurwerk sodat hulle universiteitstudie sien bloot in terme van die aanleer van spesifieke vaardighede om die regte soort werk te kry;

- en 'n beklemtoning van prestasie, afgedwing deur oormatige assessering (as onderdeel van "kwaliteitsbestuur") en ononderhandelbare sperdatums (ter wille van deurvloeikoerse) wat meewerk om kreatiwiteit, oorspronklikheid en individualiteit te marginaliseer.

In die lig van hierdie veranderde karakter van die universiteit word dié instansie vandag in kommentare dikwels beskryf as een wat in krisis verkeer, beleër is, aangeval word, beskadig of beseer is, terminaal siek is, waarvan die tyd verby is. In die inleidende hoofstuk van 'n versameling essays getiteld The assault on universities: A manifesto for resistance (2011) wat bedoel is as weerstand teen die Britse ConDem-regering se voorgestelde hoëronderwysbeleid, sê Des Freedman, een van die redakteurs:

Those of us who work in universities or who are prospective or current students are faced with the prospect of being part of a much broader coalition of resistance against the government's determination to shrink the state and, following the turmoil of the financial crisis, to restore profitability and confidence to their friends in business. But we also have another responsibility: to defend the idea of university education as a public good that is reducible neither to market values nor to instrumental reason. Attack is often the best form of defence ... we may well need industrial action, rallies, marches, occupations, teach-ins and teach-outs to defeat the transformations of our campuses into cost-centres and ideological supermarkets. But we will also need a clear vision of what the university should be: a public service, a social entitlement, a space for critical thinking and a place of discovery.

(Bailey en Freedman 2011:10)

Hierdie algemene gees van reaksie en weerstand teen die kragte van buite waaraan die universiteit blootgestel is, kom algemeen voor by diegene betrokke by hierdie instansie, en neem gewoonlik een van twee uiterstes aan, raak opgesom deur Collini (2012:20-21):

On the one hand there is the mournful idiom of cultural declinism: 'standards' are falling, 'philistinism' is rampart, 'autonomy' has been lost and even the barbarians are going to the dogs. And on the other, there is the upbeat idiom of brave new worldism: 'challenges' and 'opportunities' abound, 'partnerships with industry' beckon, and we're all 'investing in the future' .../ Attempts have been made, principally among those more sympathetic to the first rather than the second of these extremes to arrive at a defining statement of the 'idea' of the university, a timeless essence, a yardstick against which contemporary developments can be measured and found wanting.

'n Gebalanseerde reaksie sou dan iewers tussen hierdie twee uiterstes moes lê. Met erkenning aan die feit dat die karakter van universiteite nog altyd bepaal is deur die aard en behoeftes van die sosiale orde en tydsgees, moet daar gekyk word na die essensiële kenmerke van ons eie tyd en na die rol wat die universiteit in hierdie "nuwe wêreld" behoort te vervul. Ek wil in hierdie lig vervolgens fokus op die taak van Akademiese Geletterdheid en 'n saak daarvoor uitmaak 
dat hierdie vakgebied die potensiaal én verantwoordelikheid het om 'n sentrale rol te speel binne die "nuwe" universiteit om ons studente voor te berei vir die wêreld waarheen ons hulle op weg moet help.

\section{Akademiese Geletterdheid/hede en die markgedrewe universiteit}

\subsection{Algemene standpuntinname}

In 'n besinning oor die taak van Akademiese Geletterdheid binne die hedendaagse universiteitskonteks is dit in die eerste plek nodig om die amper vanselfsprekendheid te bevestig dat dit inderdaad die verantwoordelikheid is van opvoeders en ander wat deel vorm van hierdie konteks om as pleitbesorgers op te tree vir die bewaring van die essensiële en unieke waarde van die universiteit as bate vir die samelewing, naamlik as bestaansruimte vir vrye, kreatiewe, kritiese denke en vir die menslike gees se kapasiteit vir ontdekking. Maar, eerder as om van radikale middele soos industriële aksie, protesoptogte en besettings gebruik te maak soos hierbo gesuggereer, behoort akademiese middele hiervoor aangewend te word.

Die inkleding van die konsep "Akademiese Geletterdheid" is nie altyd dieselfde binne alle kontekste nie, en daar het oor die afgelope aantal dekades ook belangrike verskuiwings plaasgevind in beide die konsepsie en praktiese toepassing van kursusse gemoeid met die verbetering van geletterdheidsvlakke by universiteitstudente. Binne die Suid-Afrikaanse konteks waar hierdie tipe kursusse eers teen die begin van die nuwe millennium by universiteite 'n gevestigde instelling geraak het, word die rasionaal vir hulle invoer gekoppel aan veranderinge in die onderwyslandskap en die breër sosiale opset wat daartoe gelei het dat skoolverlaters onvoldoende voorbereid is vir suksesvolle universiteitstudie, soos weerspieël word in baie lae deurvloeikoerse. Lae taalvaardigheidsvlakke word uitgesonder as een van die hoofredes waarom studente die risiko loop om nie hulle universiteitskursusse suksesvol te voltooi nie. ${ }^{5}$ Kritici wys ook op die wyer uitkringende gevolge van hierdie risiko vir ander betrokkenes. Weideman (2003:56-57) stel dit as volg wanneer hy skryf oor die noodsaaklikheid vir die invoer van toetsing en ontwikkeling van akademiese geletterdheid spesifiek by die Universiteit van Pretoria, maar by implikasie ook by ander plaaslike universiteite:

The institutional arrangements made some three or four years ago by the University of Pretoria may perhaps have put it ahead of other institutions. Today it is no longer alone in its concern about the academic literacy levels of the students it enrols every year: most SA institutions of higher education now share that concern. They see a lack of proficiency in academic discourse as a risk (a) for students, who fail to complete their courses in time; (b) for parents (who have to foot the bill for additional years of study); (c) for themselves in the loss of subsidy; and (d) for the higher education system as a whole. Their arguments find increasing support in the literature, where academic language proficiency is linked closely to academic performance ...

\footnotetext{
${ }^{5}$ Vir voorbeelde van studies in hierdie verband, kyk: Botha \& Cilliers (1999), Leibowitz (2001), Johl (2002), Van Rensburg en Weideman (2002), Van Dyk (2005), Van Dyk \& Van der Slik (2012), Van Dyk et al. (2009), Van Dyk et al. (2011), Weideman (2003, 2011).
} 
Die vestiging van Akademiese Geletterdheid by tersiêre instansies in Suid-Afrika het dus gegroei uit die besef dat 'n goedontwikkelde akademiese taalvaardigheid (en taalverwante vermoëns) essensieel is vir akademiese prestasie. Die tipiese aard van die intervensie word as volg omskryf deur Van Dyk et. al. (2011:491):

Universiteite is dus genoodsaak om inisiatiewe van stapel te stuur ter ondersteuning van studente wat taalmatig swak voorberei is, deur onder andere aandag te skenk aan faktore soos gebrekkige akademiese geletterdheid, wat op sy beurt akademiese sukses ná inskrywing beïnvloed (Botha en Cilliers 1999, Bubb 1991:18). Die tendens blyk gevolglik te wees dat om entiteite in die lewe te roep wat onder andere daarmee gemoeid is om studente wat weens 'n onvoldoende vlak van akademiese geletterdheid of taalvaardigheid gevaar loop om in hulle studie te misluk, te ondersteun deur eerstens (taal)probleme te bepaal en dan met kursusse vorendag te kom wat dié probleme kan hanteer of oplos, soos wat tipies van toegepaste-taalkundige-omgewings verwag word.

Die situasie van gebrekkige voorbereidheid van jongmense vir die eise van tersiêre studie en die gevolglike risiko van mislukking wat die grondoorsaak was van die vestiging van Akademiese Geletterdheid by ons universiteite bestaan stereds. Die werk wat gedoen is ter motivering van die noodsaaklike intervensies en van die impak daarvan op studente se kanse op sukses was nodig in die vestigingsfase van die vakgebired. Ek wil egter hier argumenteer vir 'n formulering en praktiese toepassing van die taak van Akademiese Geletterdheid wat daaraan 'n meer integrale en sentrale plek gee in die breër taak van die universiteit. Hierdie taak lê vir my (benewens werk aan basiese taal- en ander akademiese vaardighede) in die ontwikkeling van 'n kritiese bewussyn van die sosiale kragte werksaam in die gemeenskap wat verantwoordelik is vir verskuiwings in die aard van openbare instansies soos die universiteit wat hierbo bespreek is.

\subsection{Akademiese Geletterdheid en die "nuwe" sosiale orde}

Die idee van geletterdheid as sosiale praktyk is nie nuut nie. Reeds teen die vroeë 1980's het kritici in reaksie teen die destyds aanvaarde siening van geletterdheid as 'n geïdealiseerde stel taalvaardighede en akademiese konvensies waarby studente "ingelyf" behoort te word, begin argumenteer vir ' $n$ wyer definisie wat die belangrikheid beklemtoon van sosialiseringsprosesse en 'n bemoeienis met die sosiale instellings waardeur hierdie prosesse plaasvind. In sy seminale werk Literacy in theory and practice (1984) maak Brian Street gebruik van die terme "outonoom" teenoor "ideologies" om hierdie twee benaderings te tipeer. In 'n ideologiese benadering berus geletterdheidspraktyke op spesifieke ideologieë 6 binne 'n gestratifiseerde sosiale orde. Hieruit vloei ook voort dat ons eerder moet praat van "geletterdhede" as van die enkelvoudige konsep "geletterdheid".

Die basiese konsep is verder ontwikkel in meer onlangse publikasies van Street, en ook in dié van 'n aantal ander prominente kritici soos Mary Lea, Theresa Lillis, Mary Scott en die New

\footnotetext{
${ }^{6}$ Die begrip "ideologie" word hier gesien as sisteme van idees, denkwyses of wêreldbeelde tipies van 'n gemeenskap of individu wat die basis vorm vir 'n ekonomiese of politieke sisteem, regverdiging bied vir bepaalde maniere van optrede en ingebed is in 'n bepaalde kultuur.
} 
London Group. ${ }^{7}$ Binne die omvang van 'n enkele artikel sou dit nie moontlik wees om hierdie bydraes in besonderhede te bespreek nie, maar vir die doeleindes van my argument kan die essensie hiervan opgesom word.

Die vertrekpunt van hierdie argument ${ }^{8}$ is dat ons leef in 'n tyd van intense sosiale en kulturele verandering op alle vlakke van die samelewing. Dit behels 'n verskuiwing in die verhouding tussen verskillende domeine van die sosiale orde, gesetel in 'n "kolonialisering" van ander velde deur die ekonomiese, gesien as 'n nuwe vorm van kapitalisme. Die Nuwe Kapitalisme' is eerstens informasie- of kennisgebaseer, afhanklik van nuwe kommunikasietegnologieë en netwerke op 'n globale skaal. 'n Kennisgebaseerde ekonomie beteken dat kennis 'n kommoditeit geword het: dit kan gekoop en verkoop word vir profyt, gemeet word asof dit 'n lewelose entiteit is en beoordeel word op grond van kwaliteit soos enige ander kommersiële produk. 'n Tweede belangrike kenmerk van die Nuwe Kapitalisme is dat massaproduksie vervang word met gedifferensieerde nismarkte en gesegmenteerde verkoopstrategieë. 'n Vereiste vir sukses is die vermoë tot buigsaamheid, aanpasbaarheid en samewerking aan kleiner spanprojekte eerder as om 'n onderdeel te vorm van groot, hiërargies-geordende organisasies. In die nuwe projekgefokusde werkorde werk alle spanlede saam om "produkte" te ontwerp en ontwikkel op 'n onderhandelde basis. Hiervoor is dit nodig dat alle spanlede toegerus moet wees met die diskursiewe vermoëns wat sulke onderhandeling en ontwikkeling vereis, byvoorbeeld om argumente te formuleer, voor te lê en te evalueer. Dit veronderstel ook 'n verbintenis tot "demokratiese" beginsels soos samewerking, deelname, bemagtiging en devolusie van gesag sodat bestuurders en werkers as vennote funksioneer.

Om dan terug te keer na die taak van die universiteit en die sentrale rol van Akademiese Geletterdheid hierin: as die universiteit nie meer 'n monopolie het op (of: 'n kleiner aandeel het aan) die produksie, voogdyskap en legitimering van kennis nie, wat is dan die rol van hierdie instansie in die nuwe epistemologiese orde? Dit lê vir my, in aansluiting by die siening van geletterdheid as sosiale praktyk soos hierbo uiteengesit, in 'n groter kritiese betrokkenheid by projekte en aktiwiteite in die wêreld daarbuite. By die vorm van kennis soos dit bestaan in nieakademiese omgewings is ' $n$ kritiese perspektief van minder belang as markwaarde. Daarom is dit nou belangriker as ooit dat die universiteit ' $n$ ruimte daarstel waarbinne die raamwerke, aannames en aansprake van kennis onderwerp kan word aan die tipe kritiese bevraagtekening waartoe kennisindustrieë wat net vir profyt bedryf word, nie in staat is nie, en waarin hulle ook nie geïnteresseerd is nie.

Dat Akademiese Geletterdheid 'n sentrale rol het om te vervul in die daarstelling van hierdie kritiese ruimte is in die eerste plek gesetel daarin dat in die kennisgebaseerde ekonomiese

\footnotetext{
${ }^{7}$ Vir 'n bespreking van die ontstaansgeskeidenis en algemene benadering van die New Londen Group kyk New Londen Group (1996) en die "Introduction" in Cope en Kalantzis (2000).

${ }^{8}$ Die opsomming wat in hierdie paragraaf gegee word, steun op die volgende bronne: Street (1984), New Londen Group (1996), Lea en Street (1998), Cope en Kalantzis (2000), Fairclough (2000), Gee (2000), Fairclough (2002), Gee (2003), Lea (2004), Street (2004), Fairclough ((2006), Lillis en Scott (2007), Yelland, Kalantzis en Cope (2006), Kalantzis, Cope en Cloonan (2010), Gee (2010).

9 Alternatiewe terme soos "postkapitalisme", "postfordisme" of "vinnige kapitalisme ("fast capitalism") word ook gebruik vir hierdie nuwe ekonomiese orde.
} 
stelsel, taal op die voorgrond geplaas word. Fairclough (2002:163-164) verwoord hierdie insig soos volg:

There is a sense in which language (and more broadly semiosis, including 'visual language') is becoming more central and more salient in the New Capitalism than in earlier forms of capitalism. This is implied for instance in descriptions of the New Capitalism as "knowledge-" or "information-based", its dependence upon new communication technologies, the ever-increasing importance of 'brands' and 'branding' in the economic success of products, companies, nations and even individuals, ... and the associated salience of representations and images in the media. Thus, in so far as the restructuring and re-scaling of capitalism is knowledge-led, it is also discourse-led, for knowledges are produced, circulated and consumed as discourses (economic, organizational, managerial, political, educational and so forth).

Die spektrum van geletterdhede wat nodig is vir die beheersing van die breër semiotiese werking van taal en die integrasie daarvan in die produksie, sirkulering en gebruik van diskoerse binne verskillende kontekste vorm deel van die kernbesigheid van Akademiese Geletterdheid, soos vervat in die konstruk vir die TAG- en TALL-toetse. ${ }^{10}$ Waar taalkursusse (as onderdeel van Geesteswetenskappe in die algemeen) in die resente onderwysaanpassings in Suid-Afrika dikwels afgeskaal is en in 'n ondergeskikte posisie geplaas is in vergelyking met die natuurwetenskappe wat befondsing betref, verteenwoordig die instelling van Akademiese Geletterdheid 'n hernieude bemoeienis met taal en taalverwante praktyke. Wanneer daar dan 'n saak uitgemaak word vir die waarde van Akademiese Geletterdheid behoort dit gedoen te word op grond van die potensiële bydrae van hierdie vakgebied tot die rol van die universiteit om studente voor te berei vir 'n kritiese omgang met die diverse diskoerse tipies van die hedendaagse sosiale orde.

Dit veronderstel ook verskuiwings in die wyse waarop kursusse gekonsipieer en geplaas word binne die institusionele opset. ' $n$ Basiese konseptuele verskuiwing wat nodig is, kan geïllustreer word met verwysing na die doelwitstelling vir die kursus in Akademiese Geletterdheid by my universiteit. Binne die Sentrum vir Akademiese en Professionele Taalpraktyk by die Potchefstroomkampus van die Noordwes-Universiteit word dit soos volg omskryf:

Die doel van hierdie module is om studente te help om behoorlik in 'n akademiese taalomgewing te funksioneer. Omdat jy nou aan 'n universiteit studeer, moet jy akkuraat kan lees, skryf, navorsing doen en jou werk akademies korrek kan weergee. In hierdie module maak jy kennis met akademiese taal en die korrekte wyse waarop taal in 'n akademiese omgewing gebruik word. Jy mak ook kennis met rekenaar- en inligtingsvaardighede, effektiewe studiemetodes en effektiewe lees. Die uitsluitlike doel hiervan is om jou prestasie te verbeter - indien jou werkstukke akademies korrek is, sal jou punte dienooreenkomstig hoër wees.

Omdat ' $\mathrm{n}$ mens in taal studeer, word die meeste van die opdragte aan die hand van tekste gedoen. Die vermoë om taaltekste wat inligting van verskillende aard bevat, te

\footnotetext{
${ }^{10}$ Vir 'n uiteensetting van die konstruk waarop hierdie toetse gebaseer is, kyk byvoorbeeld Van Dyk (2005), Weideman (2003, 2011).
} 
ontleed, te verstaan en te gebruik, is dus baie belangrik ten einde in staat te wees om op verskillende lewensterreine en in verskillende beroepe effektief te funksioneer.

(Van der Walt et al. 2012:v)

Hierin word prestasie en funksionering binne die akademiese omgewing vooropgestel met die verwysing na effektiewe funksionering in die gemeenskap byna as nagedagte. Hierdie ordening behoort andersom te wees, ter beklemtoning van die feit dat universiteitstudie bloot een van die fases is in die ontwikkeling van die openbare self van die indiwidu. Die geletterdheidskurrikulum behoort aktiwiteite in te sluit wat studente die geleentheid bied om te put uit ervarings van spesifieke leefwêrelde vir hulle ontwikkeling binne 'n bepaalde akademiese dissipline en dit moet gekoppel word aan werklike gemeenskappe daarbuite waarbinne hulle eendag as gegradueerdes sal moet funksioneer. In aansluiting hierby moet daar klem geplaas word op die ontwikkeling van 'n individuele identiteit met, in die woorde van Cope en Kalantzis (2000:12), vermoëns soos "adaptation to constant change through thinking and speaking for oneself; critique and empowerment; innovation and creativity; technical and systems thinking; and learning how to learn." Street (2004:13) noem die taalpraktisyn wat hierdie rol vervul 'n "praktiese epistemoloog" wat gemoeid is met "kennis in gebruik" en wat saam met studente werk binne werklike kontekste vir die ontwikkeling van wat deur Gee (2010:165) 'n "gesitueerde sosio-kulturele benadering" genoem word.

\section{Samevatting}

Die hedendaagse universiteit is, soos alle ander areas van die sosiale lewe, onderworpe aan transformasies wat neerkom op 'n toenemende besigheids- of markgerigtheid. As instansie het die universiteit ' $n$ unieke waarde vir die samelewing, naamlik as forum vir vrye, kreatiewe, kritiese denke. Singh (2012:7) wys daarop dat die behoud hiervan van besonder dringende belang is binne ontwikkelende gemeenskappe soos dié van Suid-Afrika waarin prosesse van intense sosiale transformasie onderweg is, en positiewe winste nog van embrionale aard is:

In developing country contexts with fragile public institutions and social development priorities ... it is crucial that the 'public good' functions of higher education do not disappear completely. The idea of a higher education institution as a 'social institution' has to be rehabilitated to mediate the impact of the institution conceptualized as business. This is particularly urgent in societies like South Africa where far-reaching social change is underway, where there are huge issues of poverty, inequality and social justice to be addressed and where democratic institutions and values are new or fragile and in need of reinforcement by major social institutions like those of higher education.

Akademiese Geletterdheid kan 'n sentrale rol speel in die tipe reaksie wat nodig is om die skadelike gevolge van die markgerigte universiteit teen te werk deur aan die een kant 'n bewussyn te bevorder van die eise van sosiale verandering, maar aan die ander kant aan te dring op die bydrae wat die tradisionele waardes van die universiteit hiertoe kan lewer.

\section{Verwysings}

Baker, E.A. (red.) 2010. The new literacies: Multiple perspectives on research and practice. New York: The Guilford Press. 
Bailey, M. and Freedman, D. (reds.) 2011. The assault on universities: A manifesto for resistance. Londen: Pluto Press.

Binks, M. 1999. The changing relationship between higher education and small and medium sized enterprises. In H. Gray (red.) Universities and the creation of wealth. Buckingham: The Society for Research into Higher Education \& Open University Press.

Bok, D. 2003. Universities in the marketplace: The commercialization of higher education. Princeton: Princeton University Press.

Botha, H.L. and Cilliers, C.D. 1999. Preparedness for university study: designing a thinking skills test. South African Journal of Higher Education, 13(1): 144-152.

Browne, J. 2010. Securing a sustainable future for higher education. http://www.bis.uk/assets/biscore/corporate/docs/s/10-1208-securing-sustanable-highereducation-browne-report-pdf. Besoek: 12 Feb. 2013.

Christensen, C.M. and Eyring, H.J. 2011. The innovative university: Changing the DNA of higher education from inside out. San Francisco: Jossey-Bass.

Collini, S. 2010. Bowne's Gamble. London Review of Books 32(21): 23-25.

Collini, S. 2011. From Robins to McKinsey. London Review of Books 33(16): 9-14.

Collini, S. 2012. What are universities for? Londen: Penguin Books.

Cope, B. and Kalantzis, M. 2000. Introduction: Multiliteracies: the beginnings of an idea. In B. Cope and M. Kalantzis (reds.) Multiliteracies: Literacy learning and the design of social features. Londen: Routledge.

Couldry, N. 2011. Fighting for the university's life. In M. Bailey and D. Freedman (reds.) The assault on universities: A manifesto for resistance. Londen: Pluto Press.

Durrant, G.H. 1959. The university in a technological society. Theoria 13: 12-23.

Fairclough, N. 2000. Muliliteracies and language: orders of discourse and intertextuality. In B. Cope and M. Kalantzis (reds.) Multiliteracies: Literacy learning and the design of social features. Londen: Routledge.

Fairclough, N. 2002. Editorial: language in New Capitalism. Discourse and Society 13(2): 163-166.

Fairclough, N. 2006. Language and globalization. Londen: Routledge.

Faulkner, N. 2011. What is a university education for? In M. Bailey and D. Freedman (reds.) The assault on universities: A manifesto for resistance. Londen: Pluto Press. 
Freedman, D. 2011. An introduction to education reform and resistance. In M. Bailey and D. Freedman (reds.) The assault on universities: A manifesto for resistance. Londen: Pluto Press.

Gee, J.P. 2000. New people in new worlds: networks, the new capitalism and schools. In B. Cope and M. Kalantzis (reds.) Multiliteracies: literacy learning and the design of social features. Londen: Routledge.

Gee, J.P. 2003. What video games have to teach us about learning and literacy. $A C M$ Computers in Entertainment 1(1): 1-4.

Gee, 2010. A situated-sociocultural approach to literacy and technology. In E.A. Baker (red.) The new literacies: Multiple perspectives on research and practice. New York: The Guilford Press.

Gray, H. (red.) 1999. Universities and the creation of wealth. Buckingham: The Society for Research into Higher Education \& Open University Press.

Gray, H. 1999a. Re-scoping the University. In H. Gray (red.) Universities and the creation of wealth. Buckingham: The Society for Research into Higher Education \& Open University Press.

Johl, R. 2002. Akademiese geletterdheid: van studievaardighede tot kritiese geletterdheid. Journal for Language Teaching 36(1\&2): 41-61.

Kalantzis, M. and Cope, B. 2006. On globalisation and diversity. Computers \& Composition 23:402-411.

Kalantzis, M., Cope, B. and Cloonan, A. 2010. A multiliteracies perspective on the New Literacies. In E.A. Baker (red.) The new literacies: Multiple perspectives on research and practice. New York: The Guilford Press.

Kant, Immanuel. 1979 (1897) The conflict of the faculties. Uit Duits vertaal deur Mary Gregor. Lincoln: University of Nebraska Press.

Lange, L. 2012. The public purposes of the university: a historical view, 1995-2010. In B. Leibowitz (red.) Higher education for the public good: Views from the South. Stellenbosch: SUN MeDIA.

Lea, M.R. 2004. Academic literacies: a pedagogy for course design. Studies in Higher Education 29(6): 739-756.

Lea, M. and Street, B. 1998. Student writing in higher education: an academic literacies approach. Studies in Higher Education 23(2): 157-172.

Leibowitz, B. 2001. Students' prior learning and their acquisition of academic literacy at a multilingual South African university. Ongepubliseerde PhD-verhandeling. Sheffield: University of Sheffield. 
Lillis, T. and Scott, B. 2007. Defining academic literacies research: issues of epistemology, ideology and strategy. Journal of Applied Linguistics 4(1): 5-32.

Mazzarol, T. and Soutar, G.N. 2001. The global market for higher education: Sustainable competitive strategies for the new millennium. Cheltenham, VK: Edward Elgar.

New London Group. 1996. A pedagogy of multiliteracies: designing social features. Harvard educational review 66: 60-92.

Newman, J.H. 1964(1873). The idea of a university. New York: Holt, Rinehart and Winston. NWU (Noordwes-Universiteit). s.a. Korporatiewe sake en verhoudinge.

www.nwu.ac.za/af/content/institusionele-kantoor-ksv-oor-ons. Besoek: 12 Feb. 2013.

Robertson, D. 1999. Knowledge societies, intellectual capital and economic growth. In H. Gray (red.) Universities and the creation of wealth. Buckingham: The Society for Research into Higher Education \& Open University Press.

Singh, M. 2012. Re-inserting the 'public good' into higher education and transformation. In B. Leibowitz (red.) Higher education for the public good: views from the South. Stellenbosch: SUN MeDIA.

Street, B.V. 1984. Literacy in theory and practice. Cambridge: Cambridge University Press.

Street, B. 2004. Academic literacies and the 'new orders': implications for research and practice in student writing in higher education. Learning and Teaching in the Social Sciences 1(1): 9-20.

Summerville, C.J. 2006. The decline of the secular university. Oxford: Oxford University Press.

Taylor, M. 2010. Crisis on campus: A bold plan for reforming our colleges and universities. New York: Alfred A. Knopf.

Van der Walt, J. et.al. 2012. Akademiese Geletterdheid: Studiegids vir AGLA 121. Potchefstroom: Noordwes-Universiteit.

Van Dyk, T. 2005. Towards providing effective academic literacy intervention. Per Linguam 21(2): $38-51$.

Van Dyk, T. en Van der Slik, F. 2012. Dalende akademiese geletterdheidsvlakke: feit of fiksie? Tydskrif vir Taalonderrig 46(2): 43-55.

Van Dyk, T., Zybrands, H., Cillié, K. en Coetzee, M. 2009. On being reflective practitioners: the evaluation of a writing module for first-year students in the health sciences. Southern African Linguistics and Applied Language Studies 27(3): 33-344. 
Van Dyk, T., Cillié, K., Coetzee, M., Ross, S. en Zybrands, H. 2011. Ondersoek na die impak van 'n akademiese geletterdheidsintervensie op eerstejaarstudente se akademiese taalvermoë. Litnet Akademies 8(3), Desember. www.litnet.co.za. Besoek: Mei 2012.

Van Rensburg, C. and Weideman, A.J. 2002. Language proficiency: current strategies, future remedies. Journal for language teaching 36(1-2): 152-164.

Veblen, T. 1918. The higher learning in America: A memorandum on the conduct of universities by business men. http://www.ditext.com/veblen/veb1.html. Besoek: 20 Jan 2013.

Walton, J.K. 2011. The idea of the university. In M. Bailey and D. Freedman. (reds.) The assault on universities: A manifesto for resistance. Londen: Pluto Press.

Weideman, A. 2003. Assessing and developing academic literacy. Per Linguam 19(1\&2): 5565.

Weideman, A. 2011. Academic literacy tests: design, development, piloting and refinement. Journal for Language Teaching 45(2): 100-113.

Yelland, N., Cope, B. and Kalantzis, M. 2008. Learning by design: creating pedagogical frameworks for knowledge building in the twenty-first century. Asia-Pacific Journal of Teacher Education, 36(3): 197-213. 